\title{
Managing Regulatory Blindspots: A Case Study of Leveraged Loans
}

\author{
Sung Eun (Summer) Kim $\dagger$
}

Leveraged loans have reached new peaks in the post-crisis period. This Article assesses U.S. leveraged loan regulation and highlights the ways in which the entity- or institution-based focus of regulation have been the source of critical blindspots that have limited the ability of regulators to monitor and address the risks of leveraged lending. First, the current regulatory strategy, which relies on institutions to set their own definitions of and standards for leveraged lending activities, magnifies regulatory conflicts that are inherent in a fragmented regulatory structure like the United States. Second, the institutionbased regulatory boundaries in leveraged loan regulation create regulatory gaps and exclude a significant number of leveraged loans, particularly in the market's riskiest segments, from regulatory oversight. Third, the regulatory focus on protecting individual institutions from the risks of leveraged lending may inadequately protect or even undermine the safety and soundness of the financial system. To manage these blindspots, the Article suggests a shift from an institution-based toward a loan-based perspective in the regulation of leveraged loans, and describes how this regulatory shift could be achieved by relying on the regulatory infrastructure enabled by the passage of the DoddFrank Wall Street Reform and Consumer Protection Act.

Introduction

I. The Leveraged Loan Market ............................................................... 94

II. Leveraged Loan Regulation ................................................................. 100

A. Overview of Leveraged Loan Regulation ....................................... 100

B. The Blindspots of Leveraged Loan Regulation ............................ 104

$\dagger$ Visiting Assistant Professor, University of Illinois College of Law. kimse@illinois.edu. (217) 300-0394. The author is grateful to Hilary Allen, Amitai Aviram, William Birdthistle, Richard Scott Carnell, Lynne Dallas, Lisa Fairfax, Gina-Gail Fletcher, Elisabeth de Fontenay, Julie Hill, Howell E. Jackson, Anita Krug, Bob Lawless, Tom Lin, Christina Sautter, Heidi Mandanis Schooner, Anne Tucker, Arthur E. Wilmarth and Yesha Yadav for helpful discussions and comments, to Kate Poorbaugh and Meagan Turner for invaluable research assistance, and to the editors of the Yale Journal on Regulation for outstanding editorial assistance. Many thanks also to participants in the Center for Law, Economics \& Finance (C-LEAF) at the George Washington University Law School Annual Junior Faculty Business and Financial Law Workshop, the Law \& Society Association's 2014 Annual Meeting, the 26th Annual Meeting for the Society for the Advancement of Socio-Economics (SASE), the 2014 National Business Law Scholars Conference at Loyola Law School, Los Angeles, the Big Ten Junior Faculty Conference at the IU Maurer School of Law, and various faculty workshops for helpful feedback and suggestions. Any errors herein are solely those of the author. 


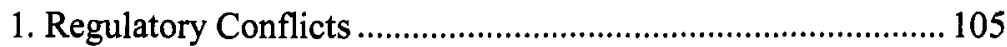

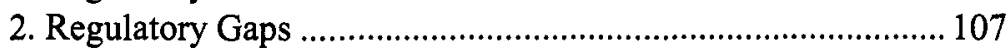

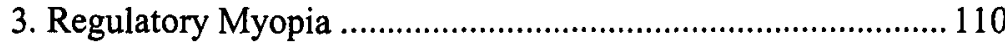

III. Managing Blindspots of Leveraged Loan Regulation ................................ 112

A. Managing Regulatory Conflicts ......................................................114

B. Managing Regulatory Gaps ............................................................116

C. Managing Regulatory Myopia ....................................................... 118

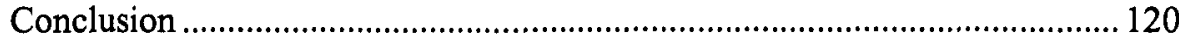

\section{Introduction}

Leveraged loans, which are loans made to companies with high levels of debt on their balance sheets, have achieved record highs in the post-crisis period, approaching nearly two trillion dollars in loans made globally. ${ }^{1}$ Leveraged loans in the United States have also reached record levels as lenders search for yield and corporate borrowers seek additional credit in the low-interest credit environment. ${ }^{2}$ Recent developments in the financial contracting, information provision, syndication, ${ }^{3}$ and secondary trading ${ }^{4}$ of leveraged loans (both outright

1. See Global Loans Review: Full Year 2013, DEALOGIC (2014), http://www.dealogic.com/media/89101/dealogic_global_loans_review_-_full_year_2013_-_final.pdf (reporting global leveraged loan volume of $\$ 1.77$ trillion in 2013).

2. Tim Cross, Leveraged Loan Volume Hits Record $\$ 537 B$ for 2013, Topping PreLehman Levels, FORBES, Nov. 8, 2013, 1:19 PM, http:/www.forbes.com/sites/spleverage/2013/11/08 /leveraged-loan-volume-hits-record-537b-for-2013-topping-pre-lehman-levels ("Loan issuance so far this year totals $\$ 537$ billion, eclipsing the $\$ 535$ billion issued in 2007 [the previous record].”).

3. Loan syndication, which is the practice of a group of two or more lenders (the syndicate) arranging a loan, is the dominant way for corporate borrowers to obtain loans. For a helpful primer on leveraged lending generally, including a description of the syndication process, see STEVEN C. Miller, STANDARD \& POOR's, LEVERAGed COMMENTARY \& DATA: A Guide to THE U.S. LoAN MARKET 5-7 (2013) [hereinafter "S\&P GUIDE"].

4. Secondary trading is the subsequent sales of loans that occur after the loans have been made. The first growth spurt in the secondary market for loans occurred in the late 1990s and early 2000s. See GlenN Yago \& Donald McCaRthy, Milken InST., The U.S. LeVERaged Loan Market: A PRIMER 23 (2004) ("From a trading volume of just $\$ 8$ billion in 1991, the secondary market for syndicated loans increased by over 1,700 percent to $\$ 145$ billion by $2003 \ldots$...). The Loan Syndications and Trading Association (LSTA) reported $\$ 170$ billion of trading volume in the secondary markets in the third quarter of 2014. See LSTA Quarterly Trade Data Study Results: Liquidity in the Secondary Loan Market Remained Robust in 3Q14, LSTA (Oct. 31, 2014), http:/www.lsta.org/uploads/ArticleModel/132/attach /3q14-lsta-quarterly-trade-data-study-results.pdf. 
and synthetically) ${ }^{5}$ have also contributed to this trend. ${ }^{6}$ Some indicators that are commonly used to determine whether a loan is leveraged include credit ratings (e.g., a rating of BB or lower on the Standard \& Poor's rating scale), the interest rate that the borrower is willing to pay (leveraged borrowers will often pay 125 or more basis points above the reference rate), and whether the loan is secured by a first or second lien. ${ }^{7}$

The financial crisis demonstrated that excessive amounts of leverage in our financial system can have large and destabilizing effects on the economy. It also exposed the deficiencies of our financial regulatory structure, which allowed highly leveraged institutions and financial products to penetrate the system in ways that undermined its safety and soundness. New agencies and guidelines for financial regulation emerged from the recent crisis, affecting highly leveraged entities and transactions. In March 2013, in response to the increasing volume of leveraged loans, the Office of the Comptroller of the Currency (OCC), the Federal Deposit Insurance Corporation (FDIC), and the Federal Reserve System (the Fed) jointly issued an updated ${ }^{8}$ supervisory guidance on leveraged lending (the "2013 Interagency Leveraged Lending Guidance"). ${ }^{9}$

5. Examples of a synthetic purchase that replicates the direct exposure to a loan include the purchase of a total rate of return swap (TRS), a loan credit default swap (LCDS), and investment in an index of leveraged loan financings. Under a TRS program, the participant purchases the income stream of the referenced loan, and LCDSs have leveraged loans as the reference instrument. Much like a holder of the referenced loan, the participant in such programs makes money by receiving the spread of the loan and loses money if the loan defaults or is marked down. For a description of the mechanics of such programs, see S\&P GUIDE, supra note 3, at 17-19.

6. This sudden growth in leveraged lending transcends borders, with similar heightened leveraged loan activity being reported across Europe and the Asia-Pacific. For recent reports on elevated leveraged lending activity in Europe, Australia, and India, see Sarbapriya Ray, Exploring Leveraged Buyout in India: An Overview, 1 INT'L RES. J. MARKETING 11 (2013); Ruth McGavin, Europe: Leveraged Loan Manager Ranks Grow for First Time Since 2007, ForBES (Jan. 21, 2014, 10:35 AM), http://www.forbes.com/sites/spleverage/2014/01/21/europe-leveraged-loan-manager-ranks-grow-for -first-time-since-2007; Foster Wong \& Paulina Duran, Australian Loan Volumes to Exceed \$100 Billion in 2014: Mizuho, BLOOMBERG, (Feb. 13, 2014, 3:08 AM), http://www.bloomberg.com/news/2014-02 -13/australian-loan-volumes-to-exceed-100-billion-in-2014-mizuho.html.

7. S\&P GUIDE, supra note 3, at 23-24 (defining leveraged loans).

8. This guidance replaces the leveraged lending guidance issued by the OCC, FDIC, and the Fed in April 2001. Unprecedented growth and risks in the market triggered the need to update the leveraged lending guidance. Office of the Comptroller of the Currency, Leveraged Lending, OCC BULLETIN 2013-9, http://www.occ.gov/news-issuances/bulletins/2013/bulletin-2013-9.html (Mar. 22, 2013) ("Since the 2001 guidance was issued, the agencies have observed tremendous growth in the volume of leveraged credit, driven in part by demand from nonregulated investors."); Derrick Cephas \& Dimia Fogam, Bank Regulators Tackle Leveraged Lending, WEIL, GoTsHAL \& MANGES LLP, FIN. REGULATORY REFORM CTR., 6 (last visited Dec. 6, 2014), http://financial-reform.weil.com/federal -reserve-board/bank-regulators-tackle-leveraged-lending/\#axzz3ItwUe0f6 ("[B]ank regulators have expressed concern that prudent underwriting practices have deteriorated and that aggregate system-wide exposure to leveraged loans has increased at an uncomfortably high rate.").

9. See DEPT. OF THE TREASURY, OFFICE OF THE COMPTROLLER OF THE CURRENCY, BD. of GOVERNORS OF THE FED. RESERVE SYS. \& THE FED. DEPOSIT INS. CORP., INTERAGENCY GUIDANCE ON LEVERAGED LENDING ACTIVITIES (2013), http://www.fdic.gov/news/news/press/2013/FR-LL -Preamble-and-Guidance.pdf [hereinafter "2013 INTERAGENCY LEVERAGED LENDING GUIDANCE"]. 
This Article provides a critical assessment of the regulation of leveraged loans, including the 2013 Interagency Leveraged Lending Guidance, and it points to the entity- or institution-based focus of regulations as the source of blindspots that have limited the ability of regulators to monitor and address the risks of leveraged lending. First, the multiplicity of agencies regulating leveraged loans, together with a regulatory strategy that delegates definition- and standards-setting to the supervised institutions, has created an inconsistent "patchwork" approach to regulation (regulatory conflicts). Second, tightly drawn regulatory boundaries exclude key players and products from the scope of leveraged loan regulation, allowing the riskiest segments of leveraged lending activities to operate in regulatory shadows (regulatory gaps). Third, due to the procyclical nature of leverage, leveraged lending is an area where "microprudential" policies, which focus on ensuring the safety and soundness of individual financial institutions, may inadequately serve or even conflict with the overarching mission of ensuring the safety and soundness of the financial system (regulatory myopia).

These blindspots are not unique to leveraged loans, and identifying and correcting them is difficult because the sources of these structural deficiencies could also be perceived as strengths of the U.S. financial regulatory system. For instance, the multiplicity of financial regulators in the United States is the source of overlaps, conflicts, and gaps in jurisdiction and regulatory authority. ${ }^{10}$ Yet such multiplicity could also be seen as a potential source of healthy regulatory diversity that facilitates a regulatory "race to the top."11 Moreover, although the allocation of regulatory authority between agencies based on tightly set definitions of financial sectors and institutions may cause a jurisdictional vacuum or shadow, ${ }^{12}$ such an approach can be effective in identifying the regulated core

10. FINANCIAL CRISIS INQUIRY COMM'N, CONCLUSIONS OF THE Fin. CRISIS INQUiRy REPORT xviii (2011) [hereinafter "FCIC REPORT"].

11. See, e.g., ROBERTA ROMANO, THE ADVANTAGE OF COMPETITIVE FEDERALISM FOR SECURITIES REGULATION (2002) (arguing that concentration of regulatory authority within a single regulator can be counterproductive and that a multiplicity of regulators could lead to more adaptive regulations in securities regulation); Amitai Aviram, Bias Arbitrage, 64 WASH. \& LEE L. REV. 789 (2007) (describing the ways in which the multiplicity of regulators creates regulatory competition that reduces incentives for regulators to manage public perceptions of how well they are regulating risk); Lawrence A. Cunningham \& David Zaring, The Three or Four Approaches to Financial Regulation: A Cautionary Analysis Against Exuberance in Crisis Response, 78 GEO. WASH. L. REV. 39, 50 (2009) (describing some advantages of a multiplexed regulatory structure).

12. See, e.g., Where Were the Watchdogs? The Financial Crisis and the Breakdown of Financial Governance: Hearing Before the S. Comm. on Homeland Sec. and Governmental Affairs, 111 th Cong. 14, 1 (2009) (testimony of Howell E. Jackson, Prof. of Law, Harvard Law School) ("Jurisdictional divisions and subdivisions based on traditional financial sectors and subsectors create regulatory gaps and piecemeal, inconsistent solutions to common problems."); Modernizing the U.S. Financial Regulatory System: Hearing Before the S. Comm. on Banking, Housing, and Urban Affairs, 111 th Cong. 128 (prepared statement of Gene L. Dodaro, Acting Comptroller General of the United States) (2009) ("The current U.S. financial regulatory system has relied on a fragmented and complex arrangement of federal and state regulators - put into place over the past 150 years - that has not kept pace with major developments in financial markets and products in recent decades."); Stephen J. Friedman \& Connie M. 
and then drawing boundary lines to limit cross-pollination between the regulated and unregulated spheres. ${ }^{13}$ This is also a proven way by which regulatory bounds can be successfully enforced. ${ }^{14}$ While this Article discusses the ways in which risk mitigation efforts in one part of the system could have a greater adverse effect on the system as a whole, managing risks of individual institutions is one step toward promoting the safety and soundness of the financial system.

I have two aims for this Article. First, I argue that the leveraged loan markets have developed in ways that magnify the inherent weaknesses (which I call "blindspots") of the traditional institution-based and microprudentiallyfocused approach to financial regulation. Second, I propose an alternative regulatory approach to manage these blindspots in leveraged loan regulation. My proposal relies on the new regulatory infrastructure and tools offered by Title I of the Dodd-Frank Wall Street Reform and Consumer Protection Act (the DoddFrank Act).

While departures from segment- or institution-based regulation have previously been explored in other contexts, ${ }^{15}$ including as a framework to

Friesen, A New Paradigm for Financial Regulation: Getting from Here to There, 43 MD. L. REV. 413, 454 (1984) (arguing that regulation by reference to institutions is less effective because clear distinctions can no longer be drawn along institutional lines); Charles K. Whitehead, Reframing Financial Regulation, 90 B.U.L. REV. 1, 20, 43 (2010) (arguing the recent trends in the financial market and the associated risks do not fit into the traditional regulatory categories and suggesting a supra-functional approach to regulation).

13. One example of such regulatory efforts of line-drawing between regulated banks and unregulated entities is Section 619 of the Dodd-Frank Act (the "Volcker Rule") which, among other things, prohibits banks from engaging in speculative trading activities unrelated to customer needs and banking relationships. Rather than broadly restricting speculative and risky financial activities, the Volcker Rule first draws a line around banking entities (defined as any insured depository institution and any affiliate or subsidiary of such entity) and then restricts these organizations' ability to engage as principal for its own trading account to purchase or sell any security for future delivery or any option thereon. This a regulatory strategy emphasizes the role of such banking entities as financial service providers and prioritizes the protection of customers of these entities by limiting the ability of these institutions to engage in activities which may create opportunities for the banking entity to breach the fiduciary duties owed to its customers. 12 U.S.C. $\S 1851$ (2012).

14. Steven L. Schwarcz, Ring-Fencing, 87 S. CAL. L. REV. 69 (2013) (discussing ringfencing which refers to regulating risks by restricting the type of activities that can be performed within a firm).

15. For a sampling of alternative approaches that have been suggested in the academic literature to address the limitations of form- or institutions-based financial regulation see, for example, MARKUS BRUNNERMEIER, ET AL., THE FUNDAMENTAL PRINCIPLES OF FINANCIAL REgULATION 25 (2009) ("The fault line of regulation should be primarily determined by the institution's actions and asset-liability structure, while its legal identity as bank, insurance company, SIV etc. should only play a secondary role"); Stephen Choi, Regulating Investors Not Issuers: A Market-Based Proposal, 88 CAL. L. REV. 279 (2000) (suggesting regulation based on the level of information available to a particular investor); Lynne Dallas, Short-termism, the Financial Crisis and Corporate Governance, 37 J. CORP. L. 265, 338-48 (2012) (discussing structural regulatory responses to the recent financial crisis); Saule T. Omarova, Wall Street as Community of Fate: Toward Financial Industry Self-Regulation, 159 U.PA. L. REv. 411, 474-82 (2011) (suggesting regulatory separation between financial firms (i) trading and dealing in complex financial instruments and (ii) providing purely traditional financial intermediation services); Morgan Ricks, $A$ Regulatory Design for Monetary Stability, 65 VAND. L. REV. 1289, 1292 (2012) (proposing functionbased regulation for short-term borrowings or IOUs which would treat short-term borrowings and traditional deposit instruments as a single functional category); Heidi Mandanis Schooner, Regulating Risk Not Function, 66 U. CIN. L. REV. 441, 474-87 (1998) (discussing risk-based regulation). In his 
reconcile the perceived limitations of existing theories, ${ }^{16}$ this Article is the first to suggest its application to leveraged loans under the post-crisis regime. The remainder of this Article proceeds as follows. Part I provides a primer and describes recent developments in the leveraged lending market. Part II undertakes a review of leveraged loan regulation (from the Shared National Credit program, put in place in 1977 to regulate large credits shared by multiple financial institutions, to the most recent 2013 Interagency Leveraged Lending Guidance jointly issued by the OCC, the FDIC, and the Fed) and identifies the blindspots that arise from the entity-focused regulatory approach. Part III makes suggestions for how to manage these blindspots by relying on the rules made pursuant to the Dodd-Frank Act.

\section{The Leveraged Loan Market}

Leveraged loans are distinguishable from other commercial loans by the debt profile of the borrower. "Leveraged" refers to the high level of debt on the borrower's balance sheet prior to or as a result of the loan transaction. Because of this, leveraged loans are associated with speculative credit ratings, which generally mean Bal or lower under Moody's, and BB or lower under Standard \& Poor's (S\&P). ${ }^{17}$ Leveraged loans typically have higher interest rates to compensate the lender for the higher default risks associated with the debt-laden, speculative-grade borrower. ${ }^{18}$

The total value of leveraged loans issued to corporate borrowers in the United States in 2013 was $\$ 605$ billion, which surpasses the pre-crisis high reached in 2007 and represents an almost eight-fold increase from 2008 levels. ${ }^{19}$

remarks regarding short-term wholesale funding regulation, Daniel K. Tarullo, a Member of the Board of Governors of the Fed, emphasized the need to supplement prudential bank regulation with a new set of policy options which "focus on particular kinds of transactions, rather than just the nature of the firm engaging the transactions." Daniel K. Tarullo, Shadow Banking and Systemic Risk Regulation: Remarks at the Americans for Financial Reform and Economic Policy Institution Conference 14 (2013), http://www.federalreserve.gov/newsevents/speech/tarullo20131122a.pdf.

16. Robert C. Merton \& Zvi Bodie, Design of Financial Systems: Towards a Synthesis of Function and Structure, 3 J. INVESTMENT MGMT. 1 (2005).

17. S\&P GUIDE, supra note 3, at 11.

18. INVESCO, LEVERAGED LOANS: AVOIDING THE INTEREST RATE TRAP (2012) ("Investors in leveraged loans are being compensated for taking credit risks.").

19. Tim Cross, Leveraged Loan Market Finishes 2013 With Record \$605B Issuance, FORBES, Dec. 20, 2013, http://www.forbes.com/sites/spleverage/2013/12/20/leveraged-loan-market -finishes-2013-with-record-605b-issuance/. 
Figure 1: U.S. Leveraged Loan Volume from 1997 through 2013

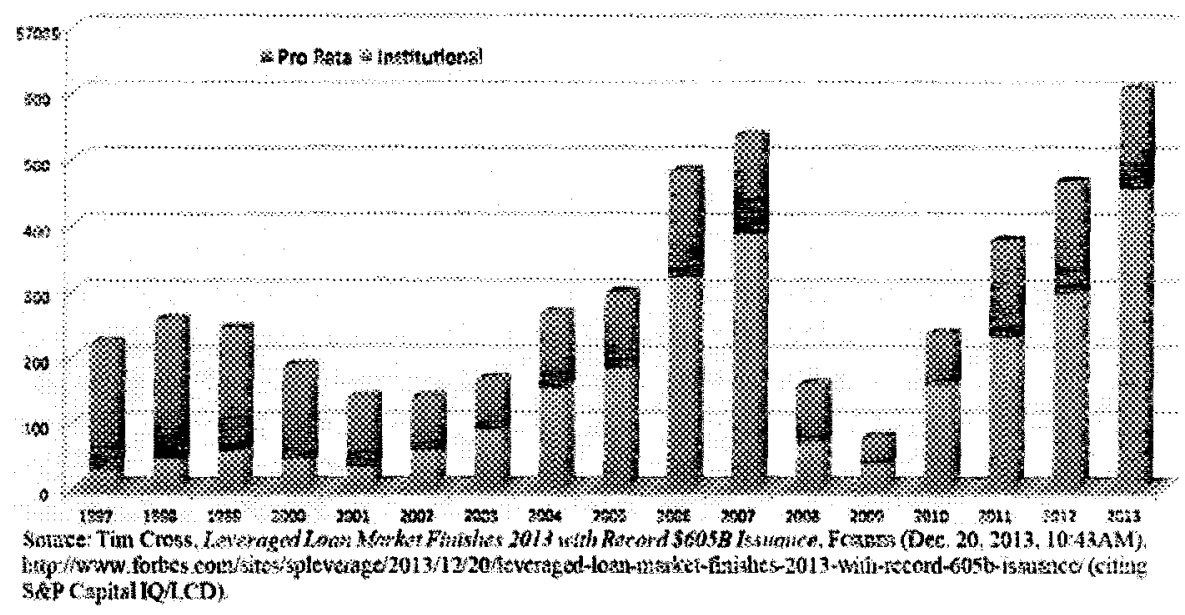

Leveraged lending volume has grown not only in absolute terms but also as a percentage of the entire loan market, with leveraged loans accounting for about $40 \%$ of new issuances in the syndicated loan markets in the third quarter of $2013 .^{20}$ Leveraged loan concentrations are at the highest they have ever been (even exceeding pre-crisis levels) and represent a significant increase from 2008 when the share of leveraged loans as a percentage of total syndicated loans was less than $10 \% .^{21}$

From the supply side, why are financial institutions willing to lend to these leveraged debtors? Shouldn't the creditworthiness of the debtor be the central concern for lenders? ${ }^{22}$ As explained by the Office of the Comptroller of the Currency in its first study of the leveraged loan segment in 1989, although "[1] at the bank," banks "look for strengths in the credit that can make up for the weaknesses." 23 Not all leveraged loans are created equal: the more senior ${ }^{24}$ or secured $^{25}$ the position of a lender, the more likely that there will be enough assets

20. See Low Rates Spur Credit Markets as Banks Lose Ground, BANK FOR INT'L SeTtLIMENTS (Dec. 8, 2013), http:/www.bis.org/publ/qtrpdf/r..qt1312a.pdf.

21. $I d$.

22. Robert C. Merton. Operation and Regulation in Financial Intermediation: A Fumctional Perspective, in OPERATION AND REGULATION OF FIN AN IAL MaRKETS 19-20 (Peter Englund ed, 1993) (explaining that financial intermediaries' principal business is the issuance of contingentpayment contracts, where "creditworthiness is the central financial issue").

23. OFFIC OF THE COMPTROILER OF THE CURRENCY, LEVERAGED FINANCING AND NATIONAL BANKS 19 (1989) [hereinafter "OCC 1989 PAPFR"].

24. Seniority is the order in which creditors will be paid out from the borrower's assets.

25. Security is the existence of and priority with respect to collateral. 
to cover the borrower's liabilities owed to that particular lender (though perhaps not enough to cover the borrower's liabilities to all lenders). To protect against the downside, lenders are able to bargain for not only priority in payment and collateral security, but also credit strengtheners such as guarantees and hedging requirements.

The migration toward riskier products in the post-crisis period can also be explained by lenders' confidence, anti-social tendencies, and stories. ${ }^{26}$ Confidence is the level of participants' trust in and reliance on certain factors that impact their decision-making. When there is a lack of confidence in the market, participants tend to become risk-averse. When there is an abundance of confidence (or over-confidence), participants tend to engage in questionable risktaking, and safeguards and regulatory checks are not as strictly enforced. For example, excessively confident institutions may flock to high-risk securities without a full review of the risks involved (and in some cases an explicit acknowledgement of the lack of such understanding) ${ }^{27}$ In short, participants are often motivated by subjective beliefs and unwarranted levels of trust in the market. ${ }^{28}$ The tendency of participants to look out for their interests at the expense of others (anti-social tendencies) can also be the source of institutions' confidence. Finally, storylines in media and industry reports chronicling doubledigit returns from leveraged loans in the higher yielding credit sectors have also been a major driver of heightened interest and competition in the lending markets. $^{29}$

On the demand side, leveraged corporate borrowers have also been eager to capitalize on the opportunities created by the low interest rate environment, ${ }^{30}$ and their improved financial condition in the post-crisis period has provided them with stronger bargaining positions as firms negotiate new loans and restructure

26. This description of behavioral characteristics of lenders borrows from the discussion of the psychological and behavioral drivers of the irrational market behaviors in GEORGE A. AKERLOF \& ROBERT J. SHILLER, ANIMAL SPIRITS: HOW HUMAN PSYCHOLOGY DRIVES THE ECONOMY, AND WHY IT MATTERS FOR GLOBAL CAPITALISM 11-59 (2009). For a description of the ways in which non-rational behaviors of capital markets can be predicted using behavioral tendencies ("animal spirits") grounded in cognitive and social psychology, see Donald C. Langevoort, Taming the Animal Spirits of the Stock Markets: A Behavioral Approach to Securities Regulation, 97 Nw. U. L. REV. 135, 153-68 (2003).

27. For an explanation of the practice referred to as "big-boy" letters, which require public-side institutions to agree to make a trade with the acknowledgement that there may be information that they are not privy to, see S\&P GUIDE, supra note 3, at 9.

28. For a discussion of how overconfidence and biased self-attribution explain certain capital markets patterns that deviate from an efficient market with rational investors, see Kent Daniel et al., Investor Psychology and Security Market Under- and Overreactions, 53 J. FIN. 1839 (1998).

29. One key source of such storylines are client publications circulated by financial service providers. See, e.g., Goldman Sachs, Asset Management: Opportunities in Senior Secured Loans, FIXED INCOME OUTLOOK, May 2013, at 1 [hereinafter "Goldman Sachs Guide"].

30. Reuters reports that nearly $70 \%$ of existing loans were expected to be refinanced or repriced in 2013 as borrowers continue to take advantage of low borrowing rates. Natalie Wright, U.S. Leveraged Loan Market Set for Another \$Itrln Year, REUTERS (Jan. 13, 2014), http://www.reuters.com /article/2014/01/13/lev-loan-outlook-idUSL2N0KN1BO20140113. 
existing loans with their lenders. ${ }^{31}$ While an individual with pre-existing debt equal to more than ten times her earnings may struggle to find a reputable financial institution that would agree to lend her additional funds, a corporation with the same leverage ratio may be able to borrow money from the same financial institution with ease and even receive favorable terms. As a prominent example, H.J. Heinz Company made headlines when it was acquired by $3 \mathrm{G}$ Capital and Berkshire Hathaway and the acquisition was financed with $\$ 9.5$ billion in loans provided by a syndicate of banks led by JPMorgan Chase \& Co. and Wells Fargo Bank N.A. As of the closing of the Heinz acquisition, Heinz was reported to have a debt to earnings ratio of about $10.4 .^{32}$

While high levels of debt on the borrower's balance sheet pose increased risks for default and loss, one reason that such a high leverage ratio does not in itself pose a barrier to borrowing for corporate debtors is that debt, up to a certain level, could be a motivator for operational efficiency. ${ }^{33}$ From a corporate finance perspective, a company is able to increase its returns by borrowing so long as the additional earnings it generates from the borrowed funds exceed the required principal payments, interest payments, and other financing costs. From a corporate governance perspective, the periodic debt payment requirement is seen as one way to curb corporate managers' tendencies to shirk their duties or mismanage excess cash flow. ${ }^{34}$ Also, for most borrowers, debt tends to be cheaper than equity, ${ }^{35}$ and among debt, syndicated loans involve lower information and contracting costs, which can be disproportionately high for a leveraged borrower. ${ }^{36}$ These conditions have given rise in the post-crisis period

31. Default rates among leveraged loans had dropped significantly to $1.5 \%$ as of February 2014 from the peak rates of more than $10.5 \%$ in 2009. Sridhar Natarajan, U.S. Leveraged-Loan Default Rate Declines to 1.5\%, Fitch Says, BLOOMBERG (Mar. 14, 2014), http://www.businessweek.com/news 12014-03-14/u-dot-s-dot-leveraged-loan-default-rate-declines-to-1-dot-5-percent-fitch-says.

32. Rating Action: Moody's Lowers Heinz Ratings Following Close of LBO, MOODY'S INVESTOR SERV. (June 19, 2013), https://www.moodys.com/research/Moodys-lowers-Heinz-ratings -following-close-of-LBO--PR_275875.

33. For a description of how debt service requirements motivate operational efficiency by serving as an aggressive performance target that keeps operations lean, see Michael C. Jensen, Agency Costs of Free Cash Flow, Corporate Finance, and Takeovers, 76 AMER. ECON. REV. 323, 328 (1986) ("[L]evering the firm so highly that it cannot continue to exist in its old form generates benefits. It creates the crisis to motivate cuts in expansion programs and the sale of those divisions which are more valuable outside the firm.").

34. Id. (describing the benefits of debt in reducing agency costs of free cash flows).

35. What Do People Mean When They Say Debt Is a Relatively Cheaper Form of Finance than Equity, INVESTOPEDIA, http://www.investopedia.com/ask/answers/05/debtcheaperthanequity.asp (last visited Nov. 13, 2014).

36. Eugene F. Fama, What's Different About Banks?, 15 J. MONETARY ECON. 29, 37-38 (1985) ("[C]ontracting costs for bank loans debt are lower for individuals and small organizations than contracting costs for outside debt" and "signals from short-term bank loans about an organization's creditworthiness can lower the information costs of other contracts"). Leveraged loan borrowers, which are by definition speculative-grade and low-credit firms, will especially benefit from such signals of creditworthiness. 
to a leveraged loan market with high volume, lower yields, fewer covenants, and higher leverage. ${ }^{37}$

Several external factors have also played a large role in expanding the reach of leveraged loans, including: 1) trading practices; 2) technology and information sharing via trade journalism; and 3) loan ratings. ${ }^{38}$ The typical leveraged loan is originated by a syndicate of lenders for distribution to a large pool of other lenders and is subsequently traded in the secondary markets. ${ }^{39} \mathrm{~A}$ designated agent assumes coordination and monitoring roles, and fund transfers are wired and received on a quick turnaround through the Fedwire. ${ }^{40}$ Non-banks such as collateralized loan obligations (CLOs), ${ }^{41}$ loan participation mutual funds, private equity firms, hedge funds, and pension funds have been active on both the borrowing ${ }^{42}$ and lending ${ }^{43}$ sides of leveraged loan transactions. In addition, leveraged loan mutual funds such as Eaton Vance Management and Fidelity Investments offer a vehicle for retail investors to access the leveraged loan market. ${ }^{44}$ Lenders and investors based in different physical locations now have the ability to conduct meetings through online platforms. ${ }^{45}$ Transaction costs have fallen due to well developed, documented, and tested procedures for voting, replacement of nonconsenting lenders, debt buybacks, and assignments and

37. Leela Parker Deo, U.S. Loan Market Makes Hay While the Sun Shines, REUTERS (July 28, 2014), http://www.reuters.com/article/2014/07/28/us-loan-heyday-idUSL2N0Q314S20140728.

38. For a study of the causal effect of the introduction of ratings on the availability of debt, see Amir Sufi, The Real Effects of Debt Certification: Evidence from the Introduction of Bank Loan Ratings, 22 REV. FIN. STUD. 1659 (2009).

39. See YAGO \& MCCARTHY, supra note 4, at 23.

40. Fedwire Services, FED. RESERVE BANK SERVICES, http://www.frbservices.org /fedwire/ (last visited Aug. 1, 2014).

41. Goldman Sachs Guide, supra note 29, at 3 ("CLO issuance more than quadrupled in the year in 2012, to approximately \$55bn, the highest issuance since the 2007 peak of \$94bn.").

42. Leveraged loans issued to private-equity sponsored portfolio companies in connection with leveraged buyouts (LBOs), refinancings, and dividend recapitalizations reached $\$ 168$ billion in the first half of 2013. Tim Cross, Led by Dell (Finally), Leveraged Loan Volume Rockets to \$20B, FORBES (Sept. 13, 2013, 11:00 AM), http://www.forbes.com/sites/spleverage/2013/09/13/led-by -dell-finally-leveraged-loan-volume-rockets-to-20b/.

43. For an account of private investment funds' entry into the lending market, see Sabrina Willmer \& Saumya Vaishampayan, Carlyle Seeks \$1 Billion as Private Equity Fills Void, BLOOMBERG (Oct. 18, 2012), http://www.businessweek.com/news/2012-10-18/carlyle-seeks-1-billion-as-privateequity-fills-void (reporting that "Carlyle Group LP (CG:US) is the biggest of at least half-a-dozen private equity firms raising funds to lend to U.S. mid-sized businesses, as dwindling returns from traditional bonds have sent investors in search of income."); see also FIN. STABILITY OVERSIGHT COUNCIL, 2013 ANNUAL REPORT $\quad 7 \quad$ (2013), $\quad$ http://www.treasury.gov/initiatives/fsoc/Documents /FSOC\%202013\%20Annual\%20Report.pdf [hereinafter "2013 FSOC ANNUAL REPORT"] (noting that pension funds and hedge funds have absorbed much of the new supply of high-yield loans and bonds in the credit markets).

44. See 2013 FSOC ANNUAL REPORT, supra note 43, at 95 chart 5.5.8 (citing Lipper data showing the increase in mutual fund holdings of high-yield bonds). These funds are also referred to as "prime funds," as they draw retail investment with the opportunity to earn the prime interest rate.

45. S\&P GUIDE, supra note 3, at 8 ("Arrangers will distribute most [Information Memos]-along with other information related to the loan, pre- and postclosing-to investors through digital platforms."). 
participations, among other state-of-the-art covenant architecture. ${ }^{46}$ Pricing information available from trade associations (chiefly the Loan Syndications and Trading Association $)^{47}$ has eased the information concerns of secondary market participants. These conditions have introduced more individuals and institutions to leveraged lending than ever before.

The diversity of the roles of banks and non-banks involved in leveraged lending transactions has further complicated the leveraged loan analysis. While a standard commercial loan is a two-way transaction comprised of the lender's extension of credit and the borrower's promise to repay, the role of financial institutions in today's leveraged lending transactions go far beyond this simple bilateral construct. A financial institution's role as lender entails different risk considerations based on whether it intends to hold the loan to maturity or distribute all or a portion of the loan and is further complicated by the additional or alternate role it or its affiliates may have in the transaction, such as administrative agent, collateral agent, subsequent purchaser, account bank, or swap provider, to name a few.

Scholars studying financial innovations have termed this phenomenon the "financial-innovation spiral," which describes the process by which financial products are initially offered by established intermediaries and then migrate to markets once they have received the information provision and standardization benefits provided by these intermediaries. ${ }^{48}$ This spiraling effect occurred in the derivatives markets as well. Derivatives were initially traded on an organized exchange (where contracts tend to be standardized, fungible, limited, transparent, and regulated) but gradually were transacted over-the-counter (where contracts tend to be private, customized, and opaque, with high levels of innovation and low levels of regulatory oversight) ${ }^{49}$ Similarly, the fully spiraled nature of the leveraged loan market has created new challenges for its regulation. The failure to reorganize regulatory boundaries in response to the tendency of financial innovations to 'spiral' would be to repeat the mistakes in derivatives regulation that, in part, caused the financial crisis. ${ }^{50}$

(2009).

46. See, e.g., Richard Wight, THE LSTA's COMPLETE CREDIt AGREEMENT GuIdE

47. About LSTA, THE LOAN SYNDICATIONS AND TRADING ASS'N, http://www.lsta.org/aboutlsta.aspx?id=98 (last visited Aug. 1, 2014).

48. E.g., Merton, supra note 22 (citing John D. Finnerty, Financial Engineering in Corporate Finance: An Overview, 17 FINANCIAL MANAGEMENT, no. 4, 1988, at 14, 14-33).

49. See, e.g., Bruce G. Carruthers, Diverging Derivatives: Law, Governance and Modern Financial Markets, 41 J. COMP. ECON. 386, 386-400 (2013).

50. FCIC REPORT, supra note 10 , at $46-58$. 


\section{Leveraged Loan Regulation}

\section{A. Overview of Leveraged Loan Regulation}

One defining feature of the U.S. financial regulatory system is the multiplicity of regulators. ${ }^{51}$ At the federal level, there are eight financial regulators $^{52}$ as well as three regulatory umbrella groups ${ }^{53}$ that oversee the financial system..$^{54}$ An implication of this regulatory structure is that two otherwise identical commercial loans could be overseen by two different regulators depending on the legal form of the originating bank. By way of illustration: the OCC, subject to the general oversight of the Treasury, regulates the lending activities of national banks, federal thrifts, and the U.S. branches of foreign banks; the Fed, comprised of twelve regional Federal Reserve Banks, oversees the loans of holding companies, state banks, and thrifts that are members of the Federal Reserve System and significant non-bank financial companies designated as such by the Financial Stability Oversight Council $;{ }^{55}$ the FDIC, an independent agency overseen by a five-member board of directors supervises the loans of the federally insured state banks and thrifts that are not members of the Fed; and the NCUA, an independent agency, oversees federal credit unions and any federally insured state credit unions. ${ }^{56}$

Among banks, the segment that dominates commercial lending has traditionally been the large national banks supervised by the Office of the Comptroller of the Currency (OCC).$^{57}$ As such, at the early development stages of the leveraged loan market, the OCC, with input from the FDIC and the Fed,

51. See, e.g., Better Broth, Still Too Many Cooks: Reforming Financial Regulation in America, ECONOMIST (June 18, 2009), http://www.economist.com/node/13862497.

52. These are the Office of the Comptroller of the Currency (OCC), the Federal Deposit Insurance Corporation (FDIC), the Federal Reserve System (the Fed), the National Credit Union Administration (NCUA), the Securities and Exchange Commission (SEC), the Commodity Futures Trading Commission (CFTC), the Federal Housing Finance Agency (FHFA), and the Bureau of Consumer Financial Protection (CFPB). While the total tally of eight remains the same, the composition of agencies has changed following the passage of the Dodd-Frank Act. Specifically, as of July 21, 2011: (i) the Office of Thrift Supervision (OTS), which previously had primary regulatory authority over federal thrifts, was abolished and its regulatory functions have been transferred to the OCC, Fed, and FDIC; and (ii) the CFPB, a new federal agency tasked with implementing and enforcing federal consumer financial laws, was created.

53. These include the Financial Stability Oversight Council (FSOC), the Federal Financial Institution Examinations Council (FFIEC), and the President's Working Group on Financial Markets. The total tally of regulatory umbrella groups increased from two to three as a result of the passage of the Dodd-Frank Act, by the addition of the Financial Stability Oversight Council (FSOC), tasked with identifying risks, filling gaps, and facilitating coordination among the regulatory agencies.

54. For an overview of the role of the eight agencies and the three umbrella groups, see MARK JICKLING \& EDWARD V. MURPHY, CONG. RESEARCH SERV., R40249, WHO REGULATES WHOM? AN OVERVIEW OF U.S. FinANCIAL SUPERVISION (2010).

55. Dodd-Frank Act $§ 115,12$ U.S.C. $\S 5325$ (2012).

56. RiChARD SCOTT CARNELL ET AL., THE LAW OF FinANCIAL INSTITUTIONS 60-63 (5th

ed. 2013).

57. See 2013 INTERAGENCY LEVERAGED LENDING GUIDANCE, supra note 9. 
had taken the lead on many regulatory efforts with respect to leveraged loans. In its supervision of large banks, the OCC seeks to ensure a banking system that satisfies five objectives: (1) sound management of risks; (2) ability to compete effectively with other providers of financial services; (3) meeting the needs of communities for credit and financial services; (4) compliance with law and regulations; and (5) fair access to financial services and fair treatment of customers. ${ }^{58}$

Of these five stated objectives, the first two objectives are directly applicable to and also in tension in leveraged loan regulation. A key challenge for regulators has been to resolve this tension. The elevated risk of default associated with leveraged lending undermines the touchstone principle of ensuring safe and sound operation of financial institutions. ${ }^{59}$ At the same time, commercial loans are among the most important assets of national banks. Among these commercial loans, the growing prevalence of leveraged loans suggests that banks will need to maintain leveraged loans in their portfolios in order to thrive in the market. 60

The regulation of leveraged loans falls under the asset quality category of the safety and soundness rules. The asset quality rating looks specifically at the credit risks associated with the loan and investment portfolio, including offbalance sheet transactions and the systems in place to manage such risks. ${ }^{61}$ The two key components of the OCC's analysis of an institution's risk consists of the quantity of risk and the quality of risk management, which encompasses the policies, processes, personnel, and control system in place to aid management's ability to identify, measure, monitor, and control the subject risks. ${ }^{62}$

In its supervision of the leveraged lending activities of banks, the OCC has identified six key risks. ${ }^{63}$ First, credit risk is the risk that the borrower will default. ${ }^{64}$ Second, price risk reflects the fluctuations in the value of the leveraged loan. ${ }^{65}$ Third, liquidity risk refers to the risk that the bank will not be able to meet

58. OfFice of the Comptroller of the Currency, EP-LBS, Large Bank SUPERVISION: COMPTROLLER'S HANDBOOK 1 (May 2013), http://www.occ.gov/publications /publications-by-type/comptrollers-handbook/lbs.pdf [hereinafter "LBS HANDBOOK"].

59. Id.

60. For reports of domestic banks' complaints that foreign counterparts have a competitive advantage in their leveraged lending activities, see Tessa Walsh \& Natalie Harrison, RLPCIFR-Lenders Cowed by Fed Rebuke on US Leveraged Loans, REUTERS, (Sept. 30, 2014), http:// www.reuters.com/article/2014/09/30/loans-fed-idUSL6N0RV4Y220140930 ("Fed-regulated banks, including Credit Suisse, Deutsche Bank and UBS, were said to have gained market share at the expense of their US peers as a result of the Fed's more lenient stance.").

61. LBS HANDBOOK, supra note 58, at 59-60.

62. Id. at 7 .

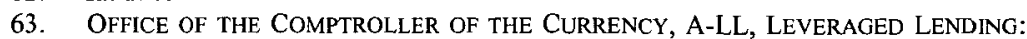
COMPTROLLER'S HANDBOOK (2008), http://www.occ.gov/publications/publications-by-type /comptrollers-handbook/_pdf/pub-ch-leveraged-lending.pdf [hereinafter "OCC HANDBOOK"].

64. Id. at 5 .

65. Id. at 8 . 
its obligations as they come due ${ }^{66}$ Fourth, compliance risk stems from violations of laws, regulations, or other standards which may be implicated by conflicts of interests and contractual and fiduciary responsibilities. ${ }^{67}$ Fifth, reputation risk is the risk from negative publicity which may arise from a bank's leveraged loan activities. ${ }^{68}$ Lastly, strategic risk refers to the risk of making poor business decisions relating to leveraged transactions in light of the bank's overall strategic goals. ${ }^{69}$

The OCC views risks as effectively managed when they are identified, understood, measured, monitored, ${ }^{70}$ and controlled in accordance with a riskreward strategy or risk appetite. In this review, the individual institution determines the threshold definition of what constitutes leveraged lending and the actual level of leveraged loan exposure that it considers to be within or in excess of the its risk appetite. The OCC relies on the individual institution's internal measures of risk to assign annual regulatory ratings. If the examiner finds that the institution is not effectively managing risk, the OCC communicates this deficiency to management and the board. The institution then must remedy this by reducing exposure, increasing capital, or strengthening risk management.

Financial regulators have from time to time separately or jointly issued specific guidelines in response to changing leveraged lending market conditions. They include: (1) the 1988 OCC examining circular regarding highly leveraged transactions; ${ }^{71}$ (2) the 1989 OCC study of leveraged financing activities; ${ }^{72}$ (3) the 1991 OCC banking issuance regarding troubled loans; ${ }^{73}$ (4) the 1999 OCC advisory letter regarding leveraged lending ${ }^{74}(5)$ the 1999 Fed supervisory letter regarding leveraged lending practices; ${ }^{75}(6)$ the 2001 interagency guidance regarding leveraged loans; ${ }^{76}(7)$ the 2008 Comptroller's Handbook on Leveraged Lending; ${ }^{77}(8)$ the 2013 Interagency Leveraged Lending Guidance ${ }^{78}$ and (9) the interagency Shared National Credit (SNC) Program. ${ }^{79}$

66. Id. at 9 .

67. Id. at 10 .

68. Id.

69. Id. at 11

70. LBS HANDBOOK, supra note 58, at 4.

71. OFFICE OF THE COMPTROLLER OF THE CURRENCY, EC-245, Highly LEVERAGED TRANSACTIONS (1988).

72. OCC 1989 PAPER, supra note 23.

73. OfFICE OF THE COMPTROLLER OF THE CURRENCY, BC-255, TROUBLED LoAN WORKOUTS AND LOANS TO BORROWERS IN TROUBLED INDUSTRIES (1991).

74. David D. Gibbons, OCC Leveraged Lending Advisory Letter AL 99-4 (May 3, 1999).

75. Richard Spillenkothen, Fed Supervisory Letter SR 99-23 (Sept. 28, 1999).

76. OFFICE OF THE COMPTROLLER OF THE CURRENCY, OFFICE OF THRIFT SUPERVISION, BoARD OF GOVERNORS OF THE FEDERAL RESERVE SYSTEM AND THE FEDERAL DEPOSIT INSURANCE CORPORATION, INTERAGENCY GUIDANCE ON LEVERAGED LENDING ACTIVITIES (2001).

77. OCC HANDBOOK, supra note 63.

78. 2013 INTERAGENCY LEVERAGED LENDING GUIDANCE, supra note 9.

79. OFFICE OF THE COMPTROLLER OF THE CURRENCY, SNC PROGRAM DESCRIPTION AND GUIDELINES (1998). Although not explicitly targeting leveraged loans, the supervisory focus of the SNC Program on interbank connectivity and size of credit creates significant overlaps with the syndicated leveraged loan segment. 
Figure 2: U.S. Leveraged Loan Regulatory Timeline

\section{5 \\ Interagency SNC Program \\ Regulates "the largest and most complex credits shared by multiple financial institutions" \\ 1989 \\ OCC: Leveraged Financing and National Banks \\ Studied how national banks defined, analyzed and monitored leveraged fmancing}

OCC: (EC-245)

Flags Highly Leveraged Transactions (HLTs) for special regulatory attention

OCC: (BC-255)

Requires banks carrying leveraged loans to maintain a well-conceived and effective workout plan for the borrower

\section{9}

\section{OCC: Leveraged Lending}

\section{Letter}

Requires more intense account and portfolio management of these loans than other lending arrangements

\section{9}

Fed: Leveraged Lending Letter Suggests a downgrade of the institution's safety and soundness rating if credit standards have been relaxed 2001

Interagency Leveraged Loan

Guidance

Sets forth the supervisory

\section{8}

OCC: Comptroller's Handbook on Leveraged Lending

Summarizes leveraged lending risks and discusses how a bank can prudently manage these risks 
In response to an increasing volume of leveraged loans and deteriorating underwriting practices, the Fed, FDIC, and OCC issued the 2013 Interagency Leveraged Lending Guidance on March 21, 2013. ${ }^{80}$ The Guidance requires financial institutions supervised by the three agencies that engage in leveraged lending transactions to, among other things, maintain sound risk-management practices, underwriting and valuation standards, management underwriting information systems, and stress tests which reflect realistic repayment assumptions. $^{81}$ Although the 2013 Interagency Leveraged Lending Guidance notes the definitions of leveraged lending commonly used within the industry ${ }^{82}$ and the agencies' own definition of the term, ${ }^{83}$ it leaves the specifics of what constitutes a leveraged loan to be determined and updated by each financial institution.

\section{$B$. The Blindspots of Leveraged Loan Regulation}

In this Section, I identify three regulatory blindspots created by misfits between the leveraged loan markets and its regulations, and show that entitybased regulation is the source of these blindspots. First, regulatory conflicts arise from the unequal treatment of functionally equivalent activities. These conflicts stem from the multiplicity of regulators in the U.S. financial regulatory system as well as the current regulatory strategy, which relies on institutions to set their own definitions and standards of leveraged lending activities. Second, regulatory gaps and shadows created by outmoded regulatory boundaries exclude significant amounts of leveraged loans, particularly at their riskiest segments, from regulatory oversight. Third, the myopic scope of the regulatory focus on protecting individual institutions from the risks of leveraged lending (microprudential concerns) at times conflicts with or inadequately serves the overarching mission of ensuring the safety and soundness of our financial system (macroprudential concerns).

80. Press Release, Board of Governors of the Federal Reserve System et al., Agencies Issue Updated Leveraged Lending Guidance (Mar. 21, 2013), http:/www.federalreserve.gov/newsevents /press/bcreg/20130321a.htm; 2013 INTERAGENCY LEVERAGED LENDING GUIDANCE, supra note 9, at 18.

81. Id.

82. A variety of metrics ranging from the use of proceeds, as well as financial ratios such as debt-to-EBITDA ratio, debt-to-net worth ratio, and debt-to-cash flow are used to determine how much an entity is burdened by debt. Id. at 22 .

83. For example, the OCC defines leveraged lending as "a transaction where the borrower's post-financing leverage, when measured by debt-to-assets, debt-to-equity, cash flow-to-total debt, or other such standards unique to particular industries, significantly exceeds industry norms for leverage." OCC HANDBOOK, supra note 63, at 3. 


\section{Regulatory Conflicts}

The overlapping and conflicting authority among multiple agencies overseeing leveraged lending has resulted in conflicts in leveraged loan regulation. This phenomenon is not unique to leveraged loans, as multiplicity in the regulatory structure is a salient feature of U.S. financial regulation. ${ }^{84}$ But the problems of regulatory arbitrage ${ }^{85}$ that arise from the differing treatment of functional equivalents become more pronounced when, as is the case with leveraged loans, the financial products being regulated is readily tradable and transferable from institution to institution.

For example, the OCC and the Fed in 1999, in response to similar concerns, issued two different letters concerning financial institutions' leveraged lending activities. The OCC letter focused on the characteristics of loans that deserve special attention and may warrant a regulatory ratings downgrade. The Fed letter focused on the financing practices of institutions rather than the features of the loan or its borrower. ${ }^{86}$ In other instances, lenders have complained about inconsistent treatment among regulators where the review teams came up with varying values of the underlying assets depending on the identity of the lender. ${ }^{87}$ And even when agencies coordinate their supervisory efforts, for instance through interagency efforts such as the 2013 Interagency Leveraged Lending Guidance, differences can be observed. Agencies have posted differing estimates of the time it would take its respondents to build and maintain a system to remain in compliance with the guidance. ${ }^{88}$ The OCC estimates $1,705.6$ hours for ongoing use versus the FDIC estimation of 529.3 hours. ${ }^{89}$ Such divergences suggest there may be different risk weightings placed on leveraged lending by the different

\footnotetext{
85. "Regulatory arbitrage" is the tendency of firms to opt for a lenient regulatory regime to reduce their regulatory burdens.

86. David D. Gibbons, OCC Leveraged Lending Advisory Letter AL 99-4 (May 3, 1999);
} notes $53-55$

84. For an overview of the multiplicity in the financial regulatory structure, see supra Richard Spillenkothen, Fed Supervisory Letter SR 99-23 (Sept. 28, 1999).

87. I thank Julie Hill for this insight. Such complaints resulted in one bank's appeal to the ombudsman that resulted in the convening of a new review team consisting of a representative from each primary federal agency. See Office of the Comptroller of the Currency, Appeals Process, QUARTERLY J., Mar. 2005, at 73-75. For an analysis of appeals of bank examiners' material supervisory decisions, see generally Julie Hill, When Bank Examiners Get It Wrong: Financial Institution Appeals of Material Supervisory Determinations, WASH. U. L. REV. (forthcoming).

88. The 2013 Interagency Leveraged Loan Guidance provides the estimated number of respondents, estimated average time per respondent, and the estimated total annual burden in connection with building and maintaining a system to comply with the Guidance. See 2013 INTERAGENCY LEVERAGED LENDING GUIDANCE, supra note 9, at 12.

89. Id. at 12-13. The 2013 Interagency Leveraged Lending Guidance explains that the variation by agency is due to "differences in the composition of the financial institutions under each agency's supervision (for example, size distribution of institutions) and volume of leveraged lending activities" but if volume of leveraged lending activities was the only explanation for the interagency divergence, a clearer approach would be to express the burden as a function of the dollar volume of leveraged loan transactions across all institutions. 
agencies or that there are varying capacities to regulate leveraged loans among different agencies, and thus that there are opportunities to reduce compliance costs associated with leveraged lending for certain types of lenders.

An additional driver of non-uniformity in leveraged loan regulation is the amount of discretion that is permitted to each institution in determining which loans are considered leveraged. The suggested definitions of leveraged loans used throughout the 2013 Interagency Leveraged Lending Guidance are merely that, suggestions. ${ }^{90}$ Instead, regulators have handed over the pen to institutions to draft the definitions of leveraged lending activities and the standards that apply to them. Allowing institutions to tailor activities to their own risk appetite could be desirable if all loans are originated and held by a single institution until maturity, ${ }^{91}$ but the present leveraged lending practice, which is often jointly arranged and widely traded, demands consistent regulation. Two institutions could be jointly arranging a loan to a high credit risk borrower, yet only one might be accounting for and reporting it as "leveraged." 92 And a third institution that may come to hold portions of both loans will treat each based on considerations unique to that holding institution. ${ }^{93}$ Reporting institutions will become wedded to (after having incurred significant expenses in developing) ${ }^{94}$ definitions that may later prove to be faulty or excessively deviant from its peers. This absence of a uniformly applicable definition of leveraged loans also creates challenges for any regulator evaluating an institution's leveraged loan limits relative to its peers and across different jurisdictions and time periods.

Regulatory diversity may well be indicative of responsive and flexible regulation. ${ }^{95}$ Professor Howell Jackson has analyzed variations in the intensity of financial regulation across jurisdictions and explains that some of the

90. 2013 INTERAGENCY LEVERAGED LENDING GUIDANCE, supra note 9, at 6 ("The proposed guidance addressed this issue [comments expressing concerns over perceived "bright line" approach to defining leveraged loans] by providing common definitions of leveraged lending and directing an institution to define leveraged lending in its internal polices").

91. See, e.g., Robert P. Bartlett III, Making Banks Transparent, 65 VAND. L. REV. 293, 300, 370-72 (2012) (discussing the benefits of modifying disclosure obligations based on banks' internal credit risk modeling and analysis when evaluating portfolio risks).

92. Edward Altman and Heather Suggitt's 2000 study is one of the few available empirical studies of the syndicated loan markets, and the authors cite the private nature of the loan market and the non-uniform nature of the data due to the differing internal ratings systems used by each bank as the "major stumbling block" in their study. Edward 1. Altman \& Heather J. Suggitt, Default Rates in the Syndicated Bank Loan Market: A Mortality Analysis, 24 J. BANKING \& FIN. 229, 232 (2000).

93. Andrew Lo \& Thomas Brennan, Do Labyrinthine Legal Limits on Leverage Lessen the Likelihood of Losses?, 90 TEX. L. REV. 1775, 1775 (2012) (describing how static constraints on leverage using "any fixed numerical limit can lead to dramatically different loss probabilities over time and across assets and investment styles").

94. The Leveraged Lending Guidance, for example, estimates that, in total, the OCC, FED and FDIC expect that the response (across seventy-five respondents) will take more than 86,280 hours. 2013 INTERAGENCY LEVERAGED LENDING GUIDANCE, supra note 9, at 12-13.

95. See generally Wulf A. Kaal, Agency Theory: Still Viable?: Essay: Dynamic Regulation of the Financial Services Industry, 48 WAKE FOREST L. REV. 791 (2013) (explaining the role of dynamic elements in financial regulation). 
variations observed might be "perfectly rational" (i.e., explainable by differences in scale, composition, and sophistication of financial services industry players, regulatory objectives, national endowments, levels of enforcement intensity, and levels of lawlessness across jurisdictions) whereas others might signal inefficient regulation (such as agency capture, path dependence, and a variety of other defects in the political process). ${ }^{96}$

Deciding which of the two explanations-rational divergence or inefficient regulation-drives observed differences in regulation requires a review of not only the underlying structural differences that could support the rational divergence explanation, but also the effectiveness of safeguards put in place to minimize inefficient regulation. In the case of leveraged loans, divergent regulatory treatment has become increasingly difficult to rationalize in light of the growing convergence among forms of financial institutions providing the leveraged lending function and their leveraged loan portfolios. ${ }^{97}$ Further, the open-ended definitions and standards-setting by financial institutions (rather than regulators) and a lack of a centralized regulatory body to review regulatory divergences suggest that stronger safeguards are needed to evaluate inconsistences in the regulation of leveraged loans.

\section{Regulatory Gaps}

Gaps in leveraged loan regulation result from the allocation of regulatory authority based on outmoded boundary lines and the shadows such allocation creates. Shadows in the financial regulatory system are pockets of certain activities, identical in function to activities performed by regulated financial institutions, which are exempt from regulatory oversight because they are performed by unregulated institutions or enjoy categorical exceptions from regulation. $^{98}$

The boundary problem specific to leveraged loans on the lending side arises from the current regime's focus on financial institutions and their activities. A leveraged loan is no longer supervised once it leaves the books of supervised banks, although its inherent risks continue to travel with the buyer and some

96. Howell E. Jackson, Variation in the Intensity of Financial Regulation: Preliminary Evidence and Potential Implications, 24 YALE J. REG. 253, 286-87 (2007). Regulation intensity is measured by inputs and costs (budget and staffing) as well as the level of securities enforcement activities (number and dollar value of sanctions).

97. For an account of the growing "homogenization" of the banking, securities, and insurance industries spurred by rapid improvements in information technology, deregulation, and financial innovations from 1975 through 2000-2001, see Arthur E. Wilmarth, Jr., The Transformation of the U.S. Financial Services Industry. 1975-2000: Competition, Consolidation, and Increased Risks, 2002 U. ILL. L. REV. 215, 222 (2002).

98. The term "shadow bank" was coined by Paul McCulley in remarks he made at the Federal Reserve Bank of Kansas City's Economic Symposium in September 2007. See Paul McCulley, Remarks at the Federal Reserve Bank of Kansas City's Economic Symposium (Sept. 5, 2007), http://www.pimco.com/EN/Insights/Pages/GCBF\%20August-\%20September\%202007.aspx. 
residual risks remain with the seller of the loan. ${ }^{99}$ Programs such as the Shared National Credit program have been partially successful in tracking the trends in non-bank involvement in large complex credit transactions, but cover only those transactions that involve at least three or more supervised institutions. ${ }^{100}$

The boundary problem specific to leveraged loans on the borrowing side is that regulations are focused on the financial condition and enterprise value of the borrower, but do not extend to the broader borrower group or the nature of the collateral. ${ }^{101}$ For example, the 2013 Interagency Leveraged Lending Guidance removes statements from the 2012 proposed guidance, ${ }^{102}$ which had required institutions to develop general guidelines for evaluating deal sponsors, and instead limits the requirement to only those loans with deal sponsors that are contractually relied on as a secondary source of repayment. ${ }^{103}$ As a result, sponsors that do not provide a formal guaranty will not be regulated. Even with respect to the subset of loans with deal sponsors, financial institutions are required only to document the sponsor's willingness and ability to support the credit. $^{104}$

In addition, certain classes of debt are given lenient treatment or enjoy exclusions from review, which may create distortions in the way market participants structure these transactions. For example, the 2013 Interagency Leveraged Lending Guidance specifies that fallen angels (loans that are not leveraged loans at the time of origination but subsequently fall into that category) should not be treated as leveraged lending transactions. ${ }^{105}$ Rather, a loan is designated as leveraged only at the time of origination, modification, extension, or refinance. This change was made in response to comments that suggested the inclusion of fallen angels would "skew reporting and tracking of the portfolio, duplicate monitoring activities, and increase costs." 106 Such exclusions,

99. See Arthur E. Wilmarth, Jr., The Dark Side of Universal Banking: Financial Conglomerates and the Origins of the Subprime Financial Crisis, 41 CoNN. L. REv. 963, 964 (2009) (explaining that even in the originate-to-distribute model, large complex financial institutions "retained residual risks under contractual and reputational commitments"); Daniel K. Tarullo, Member of the Board of Governors of the Federal Reserve System, Speech at the Americans for Financial Reform and Economic Policy Institution Conference, Washington, D.C.: Shadow Banking and Systemic Risk Regulation (Nov. 22, 2013), http://www.federalreserve.gov/newsevents/speech/tarullo20131122a.htm ("While the term 'shadow banking' implies activity outside the purview of regulatory oversight, regulated institutions are in fact heavily involved in these activities, both in funding their own operations and in extending credit and liquidity support to shadow banks beyond the regulatory perimeter.").

100. See OCC HANDBOOK, supra note 63, at 64 ("The bank regulatory agencies define a shared national credit as a loan of $\$ 20$ million or more syndicated among three or more regulated institutions.").

101. 2013 INTERAGENCY LEVERAGED LENDING GUIDANCE, supra note 9, at 10-11.

102. DEPT. OF THE TREASURY, Proposed Guidance on Leveraged Lending (2012), http://www.federalreserve.gov/boarddocs/press/foiadocs/2012/20120423/foia20120423.pdf.

103. 2013 INTERAGENCY LEVERAGED LENDING GUIDANCE, supra note 9, at 24-25.

104. Id. at 9 .

105. Id. at 8 .

106. Id. 
however, turn a blind eye to leveraged loans and borrowers that are deteriorating in financial condition. Further, a regulatory process that looks to modification, extension, or refinancing as triggering events for possible designation as a leveraged loan could discourage formal documentation of otherwise efficient modifications, extensions, or refinancings of troubled loans.

Another excluded class of loans is "traditional asset-based lending loans" (ABLs). The stated policy rationale for exclusion is that "[a]sset-based lending is a distinct segment of the loan market that is tightly controlled or fully monitored, secured by specific assets, and usually governed by a borrowing formula . . . ." 107 But this is contradicted by the fact that structured finance markets have continued to deteriorate for the fifth consecutive year. ${ }^{108}$ While regulators rely on market participants to take on the monitoring and control function for such $\mathrm{ABLs},{ }^{109}$ the banks that find it profitable to engage in this timeintensive monitoring tend to be smaller-sized companies. ${ }^{110}$

A key concern of regulatory leniency toward or exclusions of certain leveraged lending activities based on the identity of the lender or borrower is that the portion that is excluded from regulation includes the highest risk segments. The 2013 Shared National Credit (SNC) program report provides additional helpful insights on the distribution of such risks. The report studies 2012 data on lending activity and notes the increased presence of noninvestment grade and criticized credits within the sample. ${ }^{11}$ While the distribution of credits across entity types shows that the non-bank segment holds less than one-fifth of all leveraged loans within the sample, ${ }^{112}$ non-banks have a disproportionately large participation in highly stressed classified credits ${ }^{113}-\$ 122$ billion, or $62.4 \%$ of all classified credits, to be exact. Meanwhile, the institutions insured by FDIC own only $13.4 \%$ of classified assets and $9.5 \%$ of nonaccrual loans. ${ }^{114}$ While

107. Id. at 21 n.5. Recognizing the practical reality that term loans to leveraged borrowers are often extended together with a revolver that is an ABL facility, agencies have clarified that ABLs are excluded from the scope of 2013 Interagency Leveraged Loan Guidance unless "the loan is part of the entire debt structure of a leveraged obligor ...." Id. at 9.

108. S\&P Global Structured Finance Default Study, 1978-2011, STANDARD \& POOR'S (Mar. 22, 2012), http://www.standardandpoors.com/ratings/articles/en/us/?articleType=HTML\&assetID $=124533115857$.

109. 2013 INTERAGENCY LEVERAGED LOAN GUIDANCE, supra note 9, at 27-28.

110. S\&P GUIDE, supra note 3, at 9 ("Finance companies have consistently represented less than $10 \%$ of the leveraged loan market, and tend to play in smaller deals $-\$ 25$ million to $\$ 200$ million. These investors often seek asset-based loans that carry wide spreads and that often feature time-intensive collateral monitoring.").

111. Fed, FDiC, OCC, Shared National Credits Program 2012 Review 4 (Sept. 2012), https://www.fdic.gov/news/news/press/2012/pr12097a.pdf?source=govdelivery ("The 2012 SNC Review included a review of $\$ 811$ billion in credit commitments covering 29.0 percent of the $\$ 2.79$ trillion SNC portfolio. The sample was weighted toward noninvestment grade and criticized credits.")

112. Id. (stating that the distribution of credits across entity types was: $43.2 \%$ for U.S. bank organizations, $36.9 \%$ for foreign bank organizations (FBOs), and $19.8 \%$ for non-banks).

113. Id. ("Classified assets include assets rated substandard, doubtful, and loss.").

114. Id. 
individual banks may have been successful in transferring their problem loans to the non-bank segment, total levels of leveraged loans system-wide have shown a continued upward trend. ${ }^{115}$ These trends suggest that the regulatory gap has further widened and the loans in the regulatory blindspot represent higher volumes of higher risk loans.

\section{Regulatory Myopia}

The last category of blindspots created by the entity-based approach to leveraged loan regulation is that each agency's focus on protecting the lenders that it oversees from the risks of leveraged lending may conflict with the overarching mission of ensuring the safety and soundness of the financial system. For example, one group of lenders' sudden exit from the leveraged lending markets could cause or accelerate a rapid downturn in the broader leveraged lending markets, yet such lenders and their regulator may fail to internalize the impact their actions will have on the markets more generally. ${ }^{116}$ The focus of leveraged loan regulation is on the individual- and transaction-level controls: valuations, deal pipeline, management information systems, and risk ratings. ${ }^{117}$ However, built-in amplifiers in our financial system ${ }^{118}$ - such as interbank exposures, risk-based capital regulation, and the procyclical nature of leverageresult in shocks to our financial system from leveraged lending activities that are greater than the sum of the risks inherent in their parts. ${ }^{119}$

There are also important system-level and public interest considerations ${ }^{120}$ associated with leveraged loans that require a systemwide perspective in their regulation. These include the possibility of runs on the leveraged borrower, concentration risks, and pricing risks. The roots of such risks can be traced back to excessive optimism that permeates the system when private actors that bear

115. Blaise Gadanecz, The Syndicated Loan Market: Structure, Development and Implications, BIS Q. REV. 75, 84 (2004) ("US banks, whose outstanding syndicated loan commitments are regulatory monitored by the Federal Reserve Board, appear to have been relatively successful in transferring some of their syndicated credits, including up to one quarter of their problem loans, to nonbank investors.").

116. Recent orders by regulators to select banks to step out of the leveraged loan market were criticized for failing to consider negative externalities on borrowers. Kristen Haunss, Fed Loan Warning May Hurt Riskiest Borrowers, Trade Group Says, BloOMBERG BUS. (Oct. 25, 2013), http:/www.bloomberg.com/news/2013-10-24/fed-said-to-issue-warning-about-lax-leveraged-loan -underwriting.html.

117. See generally S\&P GUIDE, supra note 3.

118. For a detailed discussion of the factors that amplify shocks to our financial system see BRUNNERMEIER ET AL., supra note 15, at 13-24.

119. Id. at 13 ("The current philosophy of banking regulation-that you can make the system safe by making individual institutions safe-is an unsatisfactory basis for insuring the stability of the system as a whole.").

120. E. Gerald Corrigan, Financial Market Structure: A Longer View 4-5 (1987) (describing public interest considerations associated with banking and finance including concentration concerns, conflicts of interest, investor protection, and unfair competition). 
only a portion of the downside risks but enjoy all of the upside are the drivers of markets. ${ }^{121}$

Financial economists and legal scholars have emphasized the importance of regulating the leverage levels of both lending and borrowing entities to ensure the resilience of the financial system against amplified shocks. ${ }^{122}$ The common thread in this literature is the connection between funding conditions and asset prices. ${ }^{123}$ While the asset is held for its exchange value, which is primarily a microprudential concern, the secondary funding impact creates public externalities that require a system-level (or macroprudential) approach to their regulation.

Professor Geanakoplos outlines the eight problems of leverage, each of which highlights the ways in which actions that may enhance the safety and soundness of individual institutions may also have deleterious effects on the overall system. They are that: (1) optimistic investors impose externalities if they internalize only private losses; (2) debt overhang destroys productivity; (3) seizing collateral tends to destroy value; (4) failure to curtail leverage at high end results in a drastic fall in prices; (5) swings in asset prices have profound effects on economic activity; (6) small businesspeople that are not hedged against downturns suffer at the bottom of the cycle; (7) swings in asset prices lead to massive redistributions of wealth; and (8) government's reactive response to crisis creates inefficiencies and moral hazard. ${ }^{124}$

To synthesize this literature and its application to the present day leveraged loan markets, leveraged credit tends to be overpriced or temporarily unavailable for qualified leveraged borrowers when there is industry-wide pessimism, but underpriced and widely available when there is industry-wide optimism. ${ }^{125}$ Taking the impact of pessimism on the leverage cycle as an example, bad news (or anticipation of bad news) creates uncertainty. The exit of lenders based on actual or perceived risks (which could be likened to a run on leveraged borrowers if based on perceived rather than actual risks) impedes the availability of funds or increases cost of funds from traditional regulated sources. Collateral rates sharply increase as a response and create syndication challenges for lenders,

121. Id. at 9 .

122. See, e.g., Tobias Adrian \& Hyun Song Shin, Liquidity and Leverage, 19 J. FIN. INTERMEDIATION 418, 436 (2010) (noting the two distinct balance sheet channels which amplify financial shocks throughout system); José Gabilondo, Leveraged Liquidity: Bear Raids and Junk Loans in the New Credit Market, 34 J. CORP. L. 447, 502-04 (2009) (discussing the regulatory implications for leveraged loans); John Geanakoplos, Solving the Present Crisis and Managing the Leverage Cycle, FRBNY ECON. POL'Y REV. 104, 117 (2010) (explaining the important role of government at each stage in containing the bad news and intervening to stabilize margins and inject equity back into the system).

123. Id.

124. Geanakoplos, supra note 122, at 107-08.

125. For empirical work which shows that bank loans in particular behaved in a much more procyclical manner than their bond counterparts during the recent financial crisis, see Fiorella De Fiore \& Harald Uhlig, Corporate Debt Structure and the Financial Crisis (Soc'y for Econ. Dynamics 2012 Meeting Papers, Nov. 2012), https://www.economicdynamics.org/meetpapers/2012/paper_429.pdf. 
while otherwise qualified borrowers face reduced availability of funds or increases in the cost of funds. ${ }^{126}$

The domino effect or contagion is sped up by cross-default and crossacceleration provisions common in leveraged loan agreements. ${ }^{127}$ The aftermath is that vulture investors specializing in the purchase of distressed debt emerge as winners; ${ }^{128}$ the losers are the borrowing and lending entities that have been forced out of business. ${ }^{129}$ For this reason, a regulatory approach that ensures the rationality of individual actors and the particular agencies overseeing them is a necessary but insufficient condition for protecting the financial system against the systemic implications of inevitable downturns in the leveraged lending cycle.

\section{Managing Blindspots of Leveraged Loan Regulation}

The financial crisis revealed the extent to which using static boundaries to regulate rapidly evolving financial products allowed risk to build up in nooks and crannies in the financial system. ${ }^{130}$ This Article describes the ways in which the institution- or entity-based approach to regulating financial activities has created conflicts, gaps, and a myopic focus in leveraged loan regulation.

In this last Part of the Article, I explore the suitability of the newly formed Financial Stability Oversight Council (FSOC or "the Council"), and its data collection arm, the Office of Financial Research (OFR or "the Office"), to

126. See Geanakoplos, supra note 122 , at 106.

127. A cross default clause in a loan agreement provides that the borrower's default under another agreement will trigger an automatic event of default under this agreement. A cross acceleration clause provides that the borrower's default under another agreement will trigger an event of default under this agreement if the counterparty under the other agreement accelerates payment.

128. The Vultures Take Wing: Banks and Hedge Funds Get Ready to Capitalise on Corporate Misery, ECONOMIST (Mar. 31, 2007: (stating that the defining characteristic of the distressed debt investor is its ability to capitalize on corporate misery), http://www.economist.com/node/8929289.

129. CORRIGAN, supra note 120 , at 9 ("[F]irms seem to believe they can feather their own nests at the expense of someone else while that someone else has the same motivation but in the opposite direction. Regrettably, it would seem this process can only put further pressures on prices and spreads and thereby elevate the risk that the transition process will be disorderly-something that we must be especially sensitive to in banking and finance.").

130. See, e.g., Elizabeth F. Brown, The New Laws and Regulations for Financial Conglomerates: Will They Better Manage the Risks than the Previous Ones?, 60 AM. UNIV. L. REV. 1339, 1351-1352 \& n.60-64 (2011) (describing the supervisory authority of the now-abolished OTS over thrift holding companies like AIG). As another example, large financial conglomerates such as Bear Stearns whose demise headlined the 2007-2009 crisis, were, upon the voluntary election by such entities, supervised by the SEC as investment bank holding companies under the consolidated supervised entity (CSE) program which was abolished in 2008. For a further discussion of the CSE program's role in overseeing Bear Stearns, see SEC Office of Inspector General, REPORT NO. 446-A, SEC's OVERSIGHT OF BeAR StEARNS AND RELATED ENTITIES: CONSOlIDATED-SuPERVISED ENTITY PROGRAM (Sept. 25, 2008), http://www.sec-oig.gov/Reports/AuditsInspections/2008/446-a.pdf.; Press Release, SEC, Chairman Cox Announces End of Consolidated Supervised Entities Program (Sept. 26, 2008), $\mathrm{http}: / /$ www.sec.gov/news/press/2008/2008-230.htm. The optional nature of the CSE program and the lack of authority of the SEC were considered the key weaknesses of the program and the explanation for its failure to identify and respond to emerging risks. Id. 
manage the blindspots identified in Part II.B. In particular, I point to specific sections of the Dodd-Frank Act that make reference to not only entities but also activities and products as the primary determinants of the scope and design of financial regulation. As outlined in Section 112(a)(1) of the Dodd-Frank Act, the Council is tasked with identifying risks to U.S. financial stability that could arise from particular companies or funds, and also ongoing activities in the financial services marketplace. ${ }^{131}$

Both FSOC and OFR were created by Title I of the Dodd-Frank Wall Street Reform and Consumer Protection Act (the Financial Stability Act of 2010). ${ }^{132}$ The major reason for the creation of these two new regulatory bodies was to remedy regulators' inability under the pre-crisis regime to monitor and prevent systemic risks. In creating these agencies, Congress recognized that systemic risk could not be regulated without standardized, advanced tools for measuring systemic risks.

The Financial Stability Oversight Council consists of ten voting members (the Treasury Secretary, Fed Chair, Comptroller of the Currency, CFPB Director, SEC Chair, FDIC Chair, CFTC Chair, FHFA Director, NCUA Chair, and an independent insurance expert appointed by President) and five advisory members (the OFR Director, Federal Insurance Office Director, a designated state insurance commissioner, a designated state banking supervisor, and a designated state securities commissioner). ${ }^{133}$ The purpose of the OFR is to support the Council as it carries out its duties by collecting data, standardizing the types and format of collected and reported data, and performing applied and long-term research. ${ }^{134}$ The Office is headed by a director that is appointed by the President and is tasked with developing the tools for measuring and monitoring systemic risks. ${ }^{135}$ The Council is chaired by the Treasury Secretary and may also appoint advisory, technical, or professional committees to carry out its functions. ${ }^{136}$

Section 120 of the Dodd-Frank Act provides the Council the authority to make specific recommendations for new or heightened regulation for activities which could create or increase the risk of significant liquidity, credit, or other

131. Sections 119(a), 120(a), and 120(b)(1) of the Dodd-Frank Act provides the Council with the authority to resolve jurisdictional conflicts and apply new or heightened prudential standards and safeguards for not only specific institutions, but also specific activities and practices. 12 U.S.C. $\S \S$ 5239(a), 5330(a), and 5330(b)(1); see also Whitehead, supra note 12, at 137 (describing how the DoddFrank Act, through its creation of the FSOC, allows the regulatory response to meet the demands of a more flexible financial system).

132. Dodd-Frank Wall Street Reform and Consumer Protection Act, Pub. L. No. 111$203, \S \S 111-23,151-56,124$ Stat. 1376, 1392-1420 (2010). FSOC is created by Subtitle A and the OFR is created by Subtitle B of the Financial Stability Act of 2010.

133. Fin. Stability Oversight Council, About FSOC, U.S. DEPT. OF THE TREASURY (last updated: Oct. 14, 2014), http://www.treasury.gov/initiatives/fsoc/about/Pages/default.aspx.

134. Dodd-Frank Act $\S 153(\mathrm{a})$.

135. Id. at $\$ 152(\mathrm{~b})$.

136. Id. at $\$ 111$. 
problems spreading among bank holding companies and non-bank financial companies. ${ }^{137}$ Relying on this authority, and its power to direct the OFR, this Part highlights the ways in which the FSOC could serve a key role in managing the blindspots of leveraged loan regulation identified in Part II.

\section{A. Managing Regulatory Conflicts}

The sources of regulatory conflicts in leveraged loan regulation include the multiplicity of leveraged loan regulators and regulators' delegation of the definition and standard setting processes to financial institutions.

One of the OFR's primary functions is to standardize the types and formats of data collected by financial regulators and to develop uniform tools for risk measurement and monitoring. ${ }^{138}$ In carrying out these functions, the Office has the power to issue regulations and orders to collect and standardize data and assist member agencies in determining the types and formats of data that they may collect. ${ }^{139}$ Any such rules regarding standardization that are set by the Office will have binding effect on the member agencies. ${ }^{140}$ Any directions given by the Council or by the OFR with respect to the types and formats of data required must be implemented by the primary financial regulator in a manner acceptable to the Council. ${ }^{141}$

In this way, the OFR can play a key role in both resolving jurisdictional conflicts and disputes between agencies and setting uniform definitions for leveraged loan regulation. Leveraged lending, after all, is one of the activities identified by the Council as requiring special regulatory attention. ${ }^{142}$ To aid the Council in its determination of the applicability of heightened standards for leveraged lending activities, the OFR has the ability to ensure compliance with the methods and standards for reporting data related to leveraged lending.

Regulators have previously been successful at regulating leveraged loans with uniform benchmarks. In 1988, when the OCC first released its Examining Circular (EC-245) specific to highly leveraged transactions (or HLTs), ${ }^{143}$ it used

137. Id. at $\$ 120$.

138. Id. at $\$ 153(\mathrm{a})$.

139. Id. at $\S 153(\mathrm{c})$.

140. Id. at $\$ 153(\mathrm{c})(2)$.

141. Id. at $\$ 120(\mathrm{c})(2)$.

142. In the most recently issued FSOC Annual Report, seven concerns about financial stability are identified, among which leveraged lending activities were listed under the fifth concern, "Interest Rate Risks." See 2013 FSOC ANNUAL REPORT, supra note 43, at 3, 7, 15-16. The Report notes the elevated levels of leveraged loan issuance across the board (by depository institutions, credit unions, broker-dealers and bank holding companies) and their ability to create outsized risks to the entire system. Other areas of concern noted in the Report include reducing the susceptibility to runs in wholesale funding markets (first theme), responding to technological and operational failures (third theme), and restoring the integrity of reference interest rates such as LIBOR which serve as benchmark rates for trillions of dollars of transactions (fourth theme). Id. at 3.

143. OFFICE OF THE COMPTROLLER OF THE CURRENCY, supra note 71. 
a definition of HLTs that considered both the use of proceeds (i.e. buy-out, acquisition, or recapitalization of an existing business) ${ }^{144}$ as well as the underlying characteristics of the transaction. ${ }^{145}$ This multi-pronged definition of leveraged lending can be drafted in a way that is responsive to the fast-paced changes in leveraged loan products. ${ }^{146}$ While the substance and procedures of leveraged lending transactions has changed significantly in the past twenty-five years, EC-245 could provide a useful benchmark in creating and enforcing a uniform definition of leveraged loans. Efforts to keep these definitions current would fall under the OFR's regulatory turf.

Section 120 of the Dodd-Frank Act also requires that the specific recommendations made by FSOC be subject to public notice and comment. ${ }^{147}$ The procedural rigors of notice and comment should mitigate the rigidities of a one-size-fits-all approach to regulating leveraged loans. Comprehensive leveraged loan regulation requires the input of, among others, (1) borrowers regarding their experiences in obtaining and rolling over credit; (2) law firms specializing in borrower and lender representation regarding developments in contracting and underwriting standards; (3) accounting firms regarding deficiencies and material restatements in their audits of leveraged loan transactions and leveraged borrowers; (4) rating agencies regarding issuer and loan rating trends; and (5) trade associations regarding the leveraged lending market broadly. Such consensus-building efforts are intended to update regulatory standards to reflect trends in volume, maturity, pricing, and defaults, and to examine the drivers underlying such trends. ${ }^{148}$ By liaising with these

144. OCC HANDBOOK, supra note 63 , at 62 .

145. Id.

146. A recent study shows that banks loans are frequently amended (typically every 98 months, and almost five times during the life of the contract) to modify contractual constraints designed to mitigate information related problems. See Michael R. Roberts, The Role of Dynamic Renegotiation and Asymmetric Information in Financial Contracting (Sept. 25, 2014) (unpublished manuscript) (on file with the Social Science Research Network), http://papers.ssm.com/sol3/papers.cfm?abstract_id= 1732364 .

147. Dodd-Frank Wall Street Reform and Consumer Protection Act, Pub. L. No. 111$203, \S 120,124$ Stat. 1376, 1408-10 (2010). For an examination of the notice and comment process during pre-proposal rulemaking phase for one section of the Dodd-Frank Act (Volcker Rule), see Kimberly D. Krawiec, Don't "Screw Joe the Plummer": The Sausage-Making of Financial Reform, 55 ARIZ. L. REV. 53 (2013).

148. One example of consensus building that could serve as a useful model is the Financial Stability Board (FSB)'s recent approach to supervising financial institutions' risk cultures. FSB's stated goal is to deliver "pre-emptive, rather than reactive, outcomes-based supervision," stating that the success of anticipatory supervision depends on "the ability to engage in high-level sceptical conversations with the board and senior management on the financial institution's risk appetite framework." Increasing the Intensity and Effectiveness of Supervision; Guidance on Supervisory Interaction with Financial Institutions on Risk Culture, FIN. STABILITY BD. 1 (2013), http:// www.financialstabilityboard.org/publications/c_131118.pdf. The FSB paper explores the elements that help promote a sound risk culture such as tone from the top, accountability, opportunity to challenge decision-making processes, financial and non-financial incentives, and how regulators can identify such elements and assess the strength of risk management. Id. at 9-13. In its request for public comment, the 
stakeholders at the initial stages and on an ongoing basis, regulatory definitions can be reflective of and responsive to market developments.

\section{B. Managing Regulatory Gaps}

Gaps in regulatory oversight created a "shadow" that contributed to the recent financial crises. ${ }^{149}$ While the Dodd-Frank Act introduced reforms to address shadow banking problems revealed by the recent crisis, ${ }^{150}$ leveraged loans continue to be subject to numerous regulatory exemptions that generally leave the riskiest leveraged loans unregulated. ${ }^{151}$ The fast-paced growth and dispersion of leveraged loan activity demands a regulatory approach that canvasses all leveraged loans regardless of the form of the transacting entities, the security provided, the timing of when the loan becomes leveraged, or the identity of the borrower's ultimate parent.

One way the post-crisis reforms can facilitate this regulatory shift is by incrementally broadening the scope of regulated entities. For example, a nonbank institution and its activities may be designated as a "significant non-bank financial company" to be supervised by the Fed if FSOC finds that it is predominantly engaged in financial activities. ${ }^{152}$ This designation provides the FSOC with the ability to recommend that the Fed impose additional standards on financial activities conducted by designated companies. ${ }^{153}$ In determining whether an entity is "predominantly engaged in financial activities," FSOC looks at the activities of the entity that are "financial in nature" 154 as a percentage of the entity's total revenues or assets. ${ }^{155}$ As of November 15, 2014, only four companies-American International Group, Inc., General Electric Capital

FSB has sought suggestions for specific tools (e.g., interviews, questionnaires, analyses of internal documents, codes of ethics, or risk appetite statements) for assessments and engagement and for specific examples of good practices used to make risk culture tangible. See id. at 4; GUIDANCE ON SUPERVISORY INTERACTION WITH FINANCIAL INSTITUTIONS ON RISK CULTURE (Dec. 23, 2013), http:// www.financialstabilityboard.org/wp-content/uploads/c_131223.pdf.

149. See, e.g., Gary Gorton \& Andrew Metrick, Regulating the Shadow Banking System, BROOKINGS PAPERS ON ECON. ACTIVITY 262 (Fall 2010). Professors Gorton and Metrick point to three areas-money market mutual funds, asset securitizations, and repurchase agreements-where the regulatory and legal changes coupled with a series of financial innovations facilitated the rise of a shadow banking system that contributed to the recent financial crises.

150. Michael S. Barr, The Financial Crisis and the Path of Reform, 29 YALE J. ON REG. 91, 103 (2012) ("The Dodd-Frank Act addresses these problems [referring to the rise of shadow banking system that allowed financial firms to take on additional risk without adequate safeguards] by introducing transparency requirements and effective, consolidated supervision over the most important shadow banking instruments - over-the-counter derivatives, repurchase ('repo') agreements, and securitized assets.").

151. See supra Part II.B.ii.

152. See Definitions Relating to Title I of the Dodd-Frank Act (Regulation PP), 12 C.F.R.

$\S 242$ (2013).

153. Id.

154. The Bank Holding Company Act, 12 U.S.C. $1841 \S 4(\mathrm{k})$ (2012).

155. Dodd-Frank Act $\S 102.12$ U.S.C. $\S 5311$ (2012). 
Corporation, Inc., Prudential Financial, Inc., and Metlife, Inc. ${ }^{156}$ - have been designated as significant non-bank financial companies. Whether the private equity firms, hedge funds, pension funds, collateralized loan obligations, and loan participation mutual funds that are actively involved in leveraged lending will be subject to this designation remains to be seen. ${ }^{157}$

The Council's emphasis on gap-filling and holistic oversight provides a more immediately implementable basis for gap-filling in leveraged loan regulation. Although many of the non-bank institutions engaged in leveraged lending may not be designated as significant non-bank financial companies, they could still be subject to heightened regulation if the Council determines that the market activities they are engaged in pose a risk to financial stability. ${ }^{158}$ Such an approach can help bring into regulatory ambit certain activities that could be the source of build-up and unraveling of risks and shocks to our system, which would otherwise have been excluded due to the unregulated status of its lender or investor. ${ }^{159}$ Once the Council identifies the activities for which such a comprehensive regulatory approach is appropriate, it could rely on its data collection arm, the OFR, to develop the technical tools to regulate systemic financial risks.

These efforts to expand regulatory boundaries must also consider the efforts of our regulatory counterparts abroad. The Basel Committee on Banking Supervision (BCBS) provides a forum for international cooperation on banking supervisory matters. ${ }^{160}$ The BCBS sets forth minimum generally applicable standards for all specified areas ${ }^{161}$ (among which leveraged lending activities fall under "Credit Risk") and the principles for managing credit risk and evaluating compliance therewith is set out in the core principles. ${ }^{162}$ Specifically, these principles require supervisory access to information and ability to determine whether supervised institutions have: (1) incorporated an appropriate risk

156. Metlife, Inc. is contesting its designation as a non-bank Systemically Important Financial Institution. Metlife, Inc., Current Report (Form 8-K) (Oct. 3, 2014).

157. Up to date information regarding the designations is available on the Treasury website. Designations, U.S. DEP'T OF TREASURY, http://www.treasury.gov/initiatives/fsoc/designations /Pages/default.aspx (last visited Oct. 10, 2014).

158. Dodd-Frank Act $\S 120(\mathrm{a})$.

159. Commerce Clearing House, Dodd-Frank Wall STREet Reform and CONSUMER PROTECTION ACT: LAW, EXPLANATION AND ANAL ysIS 44-47 (2010).

160. The Basel Committee on Banking Supervision (BCBS) brings together the senior representatives of bank supervisory authorities and central banks from Argentina, Australia, Belgium, Brazil, Canada, China, France, Germany, Hong Kong, India, Indonesia, Italy, Japan, Korea, Luxembourg, Mexico, Netherlands, Russia, Saudi Arabia, Singapore, South Africa, Spain, Sweden, Switzerland, Turkey, United Kingdom, and the United States. The BCBS Core Principles Group includes representatives from member countries and regional groups of banking supervisors, as well as the IMF, World Bank, and the Islamic Financial Services Board.

161. BASEl COMM. ON BANKING SuPERVision: CORE PRINCIPles for EfFECTIVE BANKING SUPERVISION, BANK FOR INT'L SETTLEMENTS 9-14 (2012), http://www.bis.org/publ /bcbs230.pdf.

162. Id. at 46-47. 
management process; (2) properly controlled credit risk environments; (3) included credit risk exposures into stress tests; and (4) made arm's length credit decisions, among other specified criteria. ${ }^{163}$ To participate in such coordination efforts, the work of the OFR in inventorying domestic institutions' exposures to the risks of leveraged lending, irrespective of such institutions' regulated status, is needed. The ongoing work of the OFR towards developing a Legal Entity Identifier (LEI) ${ }^{164}$ to identify all parties to financial transactions will help to bridge the identified gaps in leveraged lending regulations as well.

\section{Managing Regulatory Myopia}

As discussed before, entity-based regulation may at times undermine the broader financial system's safety and soundness. Dodd-Frank's emphasis on system-level risks and FSOC's prospective approach, however, are intended to complement the predominantly institution-based and responsive approach of traditional financial regulation. Under Section 120(a) of the Dodd-Frank Act, systemic considerations are prioritized if the conduct, scope, nature, size, scale, concentration, or interconnectedness of that activity or practice could create or increase the risk of significant liquidity, credit, or other problems. ${ }^{165}$ Such efforts are needed to complement the traditional entity-focused approach of leveraged loan regulation, which may miss important amplification mechanisms in the leveraged loan cycle.

We have seen some elements of systemic risk management in past leveraged loan regulations. For example, the OCC banking issuance (the "Issuance") regarding troubled loans and loans to borrowers in troubled industries voiced concern about financial institutions unnecessarily restricting the availability of credit to sound borrowers. ${ }^{166}$ The Issuance supplemented the traditional institution-level focus of regulators by recognizing the system-level impact of lenders' herd behavior during periods of financial distress. The requirements set forth in the Issuance were intended to "help institutions avoid unnecessarily restricting the availability of credit to sound borrowers," balanced against "effects, both positive and negative, that such loans have on the bank's financial condition and results of operations."

The systemic focus of FSOC is intended to formalize this dynamic between micro- and macro-prudentially focused regulations. As a result, cooperation among FSOC and primary regulators becomes an essential element of the

163. Id.

164. 2013 FSOC ANNUAL REPORT, supra note 43, at 20.

165. Dodd-Frank Wall Street Reform and Consumer Protection Act, Pub. L. No. 111 203, § 120(a), 124 Stat. 1376, 1408-09 (2010).

166. OFFICE OF THE COMPTROLLER OF THE CURRENCY, BC-255, TROUBLED LOAN WORKOUTS AND LOANS TO BORROWERS IN TROUBLED INDUSTRIES 1 (1991).

167. Id. at 1-2. 
proposed regulatory framework. FSOC has the power to issue recommendations to primary regulators to apply additional standards and safeguards for specified financial activities. The primary financial regulator must then impose the standards recommended by the Council or similar standards otherwise acceptable to the Council. ${ }^{168}$ The implication for leveraged loan regulation is that FSOC, or its designated committee, now has the authority to superimpose regulations that mitigate systemic risk that will then supersede regulations that focus only on institutional risk mitigation (to the extent the two realms conflict).

In addition, pooling regulatory authority over leveraged lending within a single unit within the FSOC, such as a specially created committee, could create a platform to train and deploy dedicated specialists that have the tools needed to effectively oversee them. Without this platform, the costs of building up the requisite level of expertise within each individual agency will likely lead to outsourcing to private sources of some of the due diligence and monitoring functions over leveraged lending. Such outsourcing is problematic bearing in mind private monitors' known tendency to underestimate risks. ${ }^{169}$

The key strength of FSOC's approach to regulating leveraged loans is its comprehensiveness - no entity can evade or arbitrage regulation by changing its institutional structure or by using marginally different financially engineered products. However, there are two key challenges to systemic risk management regulation that FSOC must consider. First, it is not clear whether comprehensive safeguards produce a net benefit. ${ }^{170}$ Second, it may prove arduous to coordinate the regulatory efforts among the multiple leveraged loan regulators.

Bearing these challenges in mind, regulators might consider a hybrid approach that divides regulatory authority and strategy based on the degree of systemic risks inherent to an institution. Professor Brunnermeier et al. propose such a framework, ${ }^{171}$ where institutions are grouped according to a measure of risk-spillovers: "individually systemic" institutions "that are so large, so massively interconnected, and so iconic" involve the greatest spillover risk and require both macro- and micro-prudential regulation. ${ }^{172}$ Brunnermeier terms the next tier "systemic as part of a herd." 173 These are institutions whose individual conditions may not be of great concern, but whose correlated movements as a

168. Dodd-Frank Act $\S 120(\mathrm{c})$.

169. See, e.g., Geanakoplos, supra note 122, at 115 ("Some investors forgot the incentives of the rating agencies and the incentives of many market actors to downplay seriously the probability of highly correlated defaults.").

170. Section 123(a)(12) of the Dodd-Frank Act requires the Council to conduct an economic impact study of the financial services regulatory limitations intended to reduce systemic risks, which estimates the benefits and costs on capital market efficiency, the financial sector, and national economic growth. Dodd-Frank Act $\$ 123(\mathrm{a})(1)$.

171. BRUNNERMEIER ET AL., supra note 15 , at 25-26.

172. Id. at 26.

173. Id. 
"herd" may have systemic impacts. These institutions require some macroprudential regulation, but limited micro-prudential regulation. Highly levered hedge funds and private equity funds that are active in leveraged lending activities would fall under this category. The remaining groups-" "non-systemic large" and "tinies" - are institutions that have minimal systemic impact and therefore require no additional macro-prudential regulation. ${ }^{174}$ Brunnermeier's approach could be relied upon to resolve tensions between institution- versus system-based considerations that may arise in an activities-based approach to regulating leveraged loans.

\section{Conclusion}

This Article has reviewed the leveraged loan market and has identified the regulatory blindspots that distort or fail to account for pertinent risks of leveraged lending. Leveraged loans are highly complex and risky products that create networks of risks largely unobserved by the microprudential eye of primary bank supervisors. The growth of leveraged loans and the diversity of leveraged loan regulators make leveraged loans particularly susceptible to recurring regulatory avoidance and arbitrage problems. The failure of pre-crisis regulatory programs to pick up on early warnings signs of excessive leverage leading up to 2007-2009 also indicates the deficiencies of the presently fragmented approach to leveraged loan regulation.

This Article offers one way to rely on Title I of the Dodd-Frank Act and the newly created Financial Stability Oversight Council and the Office of Financial Research to manage the blindspots of leveraged loan regulation. The proposed changes to leveraged loan regulation should be regarded as a pilot program which, if successful, could be expanded to other areas of our financial system that are purveyors of similar risks and vulnerable to similar regulatory blindspots.

174. Id. 